\title{
Uczenie się w sytuacji przyjaźni w perspektywie andragogicznej
}

\author{
Adult learning in friendship in the andragogical perspective
}

Streszczenie. Tekst stanowi podsumowanie wyników badań prowadzonych w ramach pracy doktorskiej. Przedmiotem badań i refleksji jest przyjaźń osób dorosłych i uczenie się w sytuacji przyjaźni. Autorka wprowadza zjawisko - relację przyjaźni w obszar badań andragogicznych i prezentuje ich wyniki. Pokazuje, iż przyjaźń - uniwersalna przestrzeń życia człowieka współwystępuje z procesami uczenia się, realizowanego przy okazji „dziania się” przyjaźni.

Słowa kluczowe: przyjaźń, uczenie się w przyjaźni, edukacja nieformalna, raport z badań.

Summary. The text is summation research results of Ph.D. Dissertation. The subject is adult friendship and adult learning in friendship. Author introduces a phenomenon - the relationship of friendship as an area of andragogical research and presents the results. It shows that friendship - a universal space of human life - coexists with the processes of learning, realized along with the „happening” of friendship.

Keywords: friendship, learning in friendship, informal educational, research raport.

\section{Wstęp}

Niniejszy tekst jest komunikatem $\mathrm{z}$ badań przeprowadzonych w ramach pracy doktorskiej. Problematyka badań skoncentrowana została na rozpoznaniu przyjaźni osób dorosłych i jej edukacyjnego wymiaru. Uczenie się w sytuacji przyjaźni stanowi egzemplifikację uczenia się nieformalnego, które ma miejsce w nurcie życia codziennego. Prezentowane badania miały na celu poszerzenie tej wiedzy o refleksję dotyczącą uczenia się w sytuacji przyjaź- 
ni, tzn. miały ukazać czy i czego uczą się dorośli w sytuacji przyjaźni. Poniższy tekst prezentuje wyniki części badań realizowanych w ramach szerszej koncepcji badawczej.

Zjawisko przyjaźni obecne jest w myśli filozofów, socjologów, psychologów, pedagogów, antropologów i przedstawicieli innych dyscyplin naukowych. Próby wyjaśnienia fenomenu przyjaźni nie przynoszą odpowiedzi na liczne pytania. Opisywane w naukach empirycznych formy doświadczania przyjaźni nie wyczerpują jej przejawów w życiu codziennym. Zarówno badania opinii publicznej, jak i wiedza intuicyjna wskazują na istotną rolę przyjaźni w życiu ludzi. Człowiek - istota społeczna - wzrastać i rozwijać może się tylko w otoczeniu innych osób. Trwałe, bliskie stosunki interpersonalne są niezbędne do zaspokojenia potrzeby kontaktu emocjonalnego, „będącego źródłem wielu poczynań człowieka i nadającego sens jego życiu" (Niebrzydowski, Płaszczyński, 1989, s. 6), są źródłem osobotwórczej formacji człowieka. Postęp cywilizacyjny ze wszystkimi konsekwencjami, ruchliwość, mobilność społeczna wywołana procesami industrializacji i urbanizacji, prowadzi do zaniku tradycyjnych więzi rodzinnych i środowiskowych, a tym samym implikuje różne formy frustracji, osamotnienia, alienacji, czy izolacji społecznej. Temat przyjaźni wydaje się więc dzisiaj szczególnie ważny i aktualny.

Podejmując rozważania na temat przyjaźni nie sposób uniknąć pojawiających się pytań: czym jest przyjaźń? Ku czemu prowadzi? Jaką rolę pełni w życiu człowieka? Czym uwarunkowane jest jej trwanie? W rozważaniach andragogów pojawiają się ponadto pytania o wymiar edukacyjny przyjaźni: czy przyjaźń jest sytuacją, w której człowiek się uczy? Jeśli tak, to czego się uczy? Te i inne pytania dotyczące przyjaźni stały się podłożem poszukiwań badawczych autorki niniejszego tekstu. Odpowiedzi na nie badaczka poszukiwała w obszarze pedagogiki, a przede wszystkim andragogiki. Uczenie się, będące wiodącym procesem edukacji, dotyczy człowieka na przestrzeni całego jego życia i odbywa się zarówno w obszarze instytucjonalnym, jak i w sytuacjach poza nim. Procesy uczenia się ludzi dorosłych są wielowymiarowe i bardzo złożone. We współczesnej nauce „uczenie się” traktowane jako „przedsięwzięcie na całe życie”, łącząc się ściśle z ideą całożyciowego uczenia się, sytuuje się ten proces $\mathrm{w}$ obrębie interakcji konstytuujących światy ludzkiej codzienności (Dominicé, 2006, s. 10). Można przyjąć, że uczenie się w sytuacji przyjaźni jest kombinacją procesów, w trakcie których przyjaciele konstruują doświadczenie sytuacyjne oraz przekształcają je w wiedzę, umiejętności, postawy, przekonania, wartości, emocje, sensy i znaczenia oraz integrują je w obrębie własnej biografii (Jarvis za: Malewski, 2010). 
Zrozumienie natury przyjaźni, poznanie jak się rozwija, zmienia i jaką pełni rolę w życiu dorosłych może służyć wzbogaceniu tych relacji, a tym samym korzystnie wpływać na jakość życia jej uczestników. Natomiast ujawnienie edukacyjnego wymiaru przyjaźni może być punktem wyjścia do projektowania działań praktycznych. Może być początkiem drogi wiodącej dorosłych ku coraz większej otwartości, intymności, korzystnemu poszerzaniu i rozwijaniu interakcji międzyludzkich. „Wraz z rozwojem przyjaźni zwiększają się (...) możliwości zapewnienia najbardziej intymnych form wsparcia społecznego (...)" (Stewart, 2000, s. 380). Przyjaźń zapewniać może jej partnerom znaczący zakres homeostazy z najbliższym otoczeniem społecznym.

Celem badań empirycznych było rozpoznanie, opis i interpretacja zjawiska uczenia się dorosłych w sytuacji przyjaźni. Celem praktycznym było sformułowanie wniosków, postulatów ważnych dla praktyki w obszarze edukacji dorosłych.

Badaczka sformułowała dwa główne problemy badawcze: czym charakteryzuje się przyjaźń w opiniach badanych osób dorosłych oraz jakie uczenie się realizują w sytuacji przyjaźni? Pytania te uszczegółowiono, do każdego z nich sformułowano hipotezy badawcze, uwzględniono zmienne i liczne podzmienne. $\mathrm{Z}$ uwagi na ograniczenia formalne nie zostały one zaprezentowane w niniejszym tekście. W badaniach zastosowano metodę sondażu diagnostycznego, technikę ankiety i narzędzie w formie kwestionariusza ankiety. Badania zrealizowane zostały na terenie Łodzi, respondentów rekrutując z pięciu instytucji działających na obszarze osiedla Teofilów. Łącznie w badaniach uczestniczyło 188 osób, dobranych w sposób nielosowy, celowy, za kryterium doboru przyjmując wiek chronologiczny badanych (od 18 do 80 roku życia). W analizie materiału uzyskanego na podstawie kwestionariusza ankiety wykorzystano elementy statystyki opisowej i statystyki indukcyjnej. Do opisu zastosowano także miary tendencji centralnej i wnioskowanie statystyczne. Do analizy statystycznej wyników wykorzystano rozkłady częstości i tabele krzyżowe zmiennych (w oparciu o dane procentowe) oraz test niezależności zmiennych. Materiał badawczy został poddany analizie statystycznej przy wykorzystaniu pakietów programu SPSS Statistic.17.0. Dane liczbowe uzyskane w ten sposób pozwoliły na dokonanie charakterystyki badanego zjawiska, ocenę różnic i podobieństw między elementami badanej zbiorowości. 


\section{Anna Gutowska}

\section{Charakterystyka próby badawczej}

Populacja badanych osób, licząca łącznie 188 osób, to populacja różnicowana pod względem wieku, płci, poziomu wykształcenia, stanu cywilnego, aktualnej sytuacji zawodowej, stanu rodzinnego. Rozkład cech nie rozkłada się równomiernie. Wśród badanych przeważają kobiety (126 osób), których jest niemal dwukrotnie więcej niż mężczyzn (62 osoby). Respondentów, ze względu na wiek, podzielono na cztery grupy wiekowe: badanych w okresie przedproża dorosłości (18-25 lat) - 22\% badanej populacji, w okresie wczesnej dorosłości (25-40 lat) - 26\% badanej populacji, w okresie środkowej dorosłości (40-60/65 lat) - 30\% badanej populacji i późnej dorosłości (60/65-80 lat) $)^{1}-22 \%$ badanej populacji. Wśród respondentów uwidoczniono wyższy poziom wykształcenia formalnego niż wskazują na to aktualne tendencje. Najwyższy poziom wykształcenia reprezentowały osoby w okresie wczesnej dorosłości, najniższy - osoby w okresie późnej dorosłości. Badaną populację można uznać za dość jednorodną pod względem stanu cywilnego - prawie $60 \%$ osób pozostawało w związkach partnerskich. W stanie panieńskim i kawalerskim najczęściej pozostawali badani w okresie przedproża dorosłości, a największy odsetek owdowiałych - w późnej dorosłości. Respondenci w większości przypadków wchodzili w skład gospodarstw domowych składających się przynajmniej z dwóch osób, a jednoosobowe gospodarstwa prowadziło około $13 \%$ badanych. Ponad połowa prowadziła gospodarstwa wspólnie ze współmałżonkiem, w tym znakomita większość ze współmałżonkiem i dziećmi. Blisko $1 / 4$ badanych prowadziła gospodarstwo ze swoimi rodzicami, a prawie $7 \%$ mieszkało z dziećmi. Zdecydowana większość, blisko 70\% badanych, to osoby aktywne zawodowo (54\%) lub studiujące (15\%). Niecałe $7 \%$ to osoby bierne zawodowo, a ponad $20 \%$ to emeryci.

Analiza materiału badawczego pozwoliła na uzyskanie opinii badanych na temat przyjaźni - jej definiowania, przypisywanych cech, obrazu aktualnych przyjaźni i ich charakterystyki oraz uczenia się w sytuacji przyjaźni, jego zakresów, obszarów, wymiarów i barier. Poniżej, z uwagi na ograniczoną objętość tekstu, zamieszczono jedynie ogólne podsumowanie, bez prezentacji wskaźników liczbowych.

1 Periodyzację dorosłości przyjęto za E. Dubas, Etapy dorosłości i proces kształcenia w: A. Fabiś, B. Cyboran (red.), Dorosły w procesie kształcenia, Bielsko-Biała- Zakopane, 2009, s. $115-132$. 


\section{Definiowanie przyjaźni}

Pozyskane dane dotyczące definiowania przez badane osoby dorosłe przyjaźni w znacznej mierze potwierdziły definicyjne ustalenia przyjęte w teoretycznych rozważaniach pracy. W wypowiedziach respondentów ujawniła się dominacja rozumienia przyjaźni jako relacji międzyludzkiej opartej na zaufaniu, otwartości, wsparciu i więzi emocjonalnej, czyli jej atrybutach oraz jako szczególnej formy bliskości z drugim człowiekiem. Tym samym można stwierdzić, że potoczna świadomość i rozumienie przyjaźni nie odbiega daleko od rozważań teoretycznych. Można więc powiedzieć, że definiowanie przyjaźni przez badane osoby dorosłe jest dość zgodne z literaturą przedmiotu. Należy także zauważyć, że spostrzeganie przyjaźni przez respondentów odnosi się znacznie częściej do jej klasycznego ujęcia, gdzie przeciwstawia się ją miłości, a podkreśla cechy ją konstytuujące. Ponadto wyniki badań pozwoliły także na potwierdzenie założenia, że rozumienie pojęcia „przyjaźń" jest, choć niezbyt silnie, uzależnione od płci respondentów. Badane kobiety częściej relacji tej nadawały charakter uczuciowo-emocjonalny.

\section{Zewnętrzne czynniki określające przyjaźń}

Przyjaźń badanych jest relacją dynamiczną, nie stanowi struktury zamkniętej i podlega różno

rodnym czynnikom wewnętrznym i zewnętrznym, które determinują jej rozumienie. Jak wynika z analizy, przyjaźnie badanych dorosłych określane były przez takie czynniki zewnętrzne, jak: czas trwania przyjaźni, częstotliwość kontaktów, formy kontaktów i miejsca kontaktów:

\section{Czas trwania przyjaźni}

Analiza czasu trwania przyjaźni badanych dorosłych wykazała, iż jest on dość długi, tzn. przyjaźnie respondentów zazwyczaj trwają dłużej niż pięć lat, ale nie krócej niż rok. W badaniach potwierdzenie znalazła zależność czasu trwania przyjaźni i etapu dorosłości. Najmłodsi respondenci deklarowali krótszy czas trwania przyjaźni, najstarsi - najdłuższy. Ponadto potwierdza to nie tylko poglądy autorów, których zdaniem rozwój relacji interpersonalnych jest długotrwałym procesem, ale również fakt, iż wiele z nich zawieranych jest w okresie dzieciństwa i młodości. Przyjaźń jest relacją rozwojową, 


\section{Anna Gutowska}

wymagającą czasu, a jak twierdzą P. L. Bergera i T. Luckmana (1983), każde kolejne spotkanie przyjaciół jest jednocześnie utrwaleniem ich związku. Należy także zauważyć, że czas trwania przyjaźni nie jest skorelowany z płcią, ani z innymi zmiennymi społeczno-demograficznymi.

\section{Płeć przyjaciół}

Analiza danych dotyczących płci przyjaciół respondentów pozwala zauważyć, że badani dorośli, bez względu na wiek i płeć najczęściej przyjaźnią się z osobami obu płci. Badani bardzo rzadko przyjaźnią się tylko z osobami odmiennej płci, częściej na przyjaciół wybierają przedstawicieli tej samej płci. Należy przy tym zauważyć, że zależność ta wygląda nieco inaczej w przypadku najbliższych przyjaciół, gdzie w przeważającej części są to osoby tej samej płci. Na uwagę zasługuje także fakt, iż najbliższego przyjaciela odmiennej płci deklarowały głównie osoby w później dorosłości. Wychodząc z założenia, że przyjaźń jest uczuciem trwalszym niż miłość i, że z miłości może zrodzić się przyjaźń, znajduje to swoje uzasadnienie. A. Schopenhauer pisał, że „z uczuciem miłości łączy się często uczucie przyjaźni, oparte na podobieństwie poglądów. Ale to uczucie rodzi się później, kiedy miłość została zaspokojoną" (1903, s. 55). Potwierdzenia tych słów można też szukać w fazach związku miłosnego Sternberga. W jednej z nich, nazwanej fazą przyjacielską, dominującymi elementami relacji są wzajemne zaufanie, sympatia, chęć pomagania i otrzymywania pomocy. Dla wielu ludzi wejście w fazę związku przyjacielskiego oznacza najbardziej satysfakcjonujący okres dla ich relacji (Wojciszke, 2004). Wyniki badań pokazują także, że inne cechy społeczno-demograficzne nie wykazują cech korelacji z płcią przyjaciół badanych dorosłych. Podobne zależności można zauważyć w analizie danych dotyczących wieku przyjaciół respondentów. Najczęściej badani dorośli przyjaźnią się z rówieśnikami, w zbliżonym wieku są też ich najbliżsi przyjaciele. Inne cechy społeczno-demograficzne także nie wykazały tu cech zależności.

\section{Częstotliwość i formy kontaktów przyjaciół}

Analiza częstotliwości kontaktów z przyjaciółmi ujawniła, że badani dorośli najczęściej kontaktują się ze swoimi przyjaciółmi od kilku razy dziennie do kilku razy w roku. Widoczna jest zależność, że wraz z wiekiem częstotliwość kontaktów jest niższa - najczęściej kontaktują się ze sobą badani najmłod- 
si, najrzadziej najstarsi. Płeć oraz inne analizowane cechy społeczno-demograficzne nie wykazują w tej analizie cech istotności. Dorośli kontaktują się z przyjaciółmi zarówno w sposób bezpośredni jak i pośredni, jednak preferowaną formą kontaktów, bez względu na wiek, płeć i inne cechy społeczno-demograficzne, nadal są kontakty bezpośrednie „twarzą w twarz”. W przyjaźni ta forma ma szczególne znaczenie, gdyż oczywistym jest, iż kontakty bezpośrednie wydają się być najbardziej wartościowe, pozwalają na wzajemne poznanie, zrozumienie i rozwój relacji. Skuteczniej też, niż to ma miejsce $\mathrm{w}$ kontaktach pośrednich, zapobiegają wszelkim nieporozumieniom. Jednak współczesny świat, niezwykle szybko postępujący rozwój nowoczesnych technologii, oferuje człowiekowi nowe kanały kontaktów, a ich bogatym źródłem jest między innymi Internet. Analiza form kontaktów potwierdziła, iż młodzi ludzie częściej korzystają z tych możliwości, tzn. najmłodsi respondenci częściej kontaktują się z przyjaciółmi za pośrednictwem telefonu komórkowego (wykorzystując jego różne funkcje, m.in. wiadomości SMS i MMS) czy komputera, najrzadziej korzystają z tych form badani najstarsi. Można przypuszczać, że sytuacja ta, w środowisku osób starszych, może być spowodowana zarówno brakiem dostępności do niezbędnych narzędzi, brakiem umiejętności ich obsługi, ale i brakiem zainteresowania nowoczesną technologią.

\section{Miejsca spotkań przyjaciół}

Miejsca spotkań badanych z przyjaciółmi można określić jako różnorodne (zarówno prywatne, jak i publiczne), jednak najczęściej badani dorośli spotykają się z przyjaciółmi w swoich miejscach zamieszkania. Są one zależne od płci oraz wieku badanych. W przypadku młodszych respondentów (etap przedproża i wczesnej dorosłości) dominują publiczne miejsca spotkań, a dorośli w późniejszych etapach dorosłości częściej spotykają się z przyjaciółmi w miejscach prywatnych (miejsce zamieszkania). Można także zauważyć, że częściej miejsca prywatne preferowały kobiety niż mężczyźni. Wyniki badań uwidoczniły ponadto, że najmłodsi badani dorośli znacznie częściej niż pozostali spotykają się z przyjaciółmi w lokalach gastronomiczno-rozrywkowych, punktach usługowo-handlowych i miejscach nauki. $\mathrm{Na}$ uwagę zasługuje także fakt, iż respondenci stosunkowo rzadko na miejsce spotkań wybierają instytucje kulturalne (spośród nich najczęściej kino), zaś najrzadziej spotykają się z przyjaciółmi w organizacjach społecznych i wyznaniowych. 


\section{Wewnętrzne czynniki określające przyjaźń}

Badanie wewnętrznych cech przyjaźni ujawniło, że w badanej populacji zaufanie, to najistotniejsza cecha konstytuująca przyjaźń. Potwierdza to zgodność wiedzy i odczuć badanych z ogólnymi rozstrzygnięciami teoretycznymi, gdzie zaufanie jest jednym $z$ fundamentów i podstawowych więzów przyjaźni. Jest gwarantem uszanowania odmienności i podmiotowego traktowania partnera. Umacnia relację, poprawia komunikację i podnosi atrakcyjność partnerów. Badani wysoko ocenili także możliwość uzyskania w przyjaźni pomocy i wsparcia. W wielu badaniach nad przyjaźnią dowodzi się, że pomoc stanowi jedną z podstawowych wartości przypisywanych tej relacji ${ }^{2}$. Ta cecha przyjaźni nabiera znaczenia w sytuacjach trudnych, problemowych, stresujących. Może przybierać formę zarówno konkretnej pomocy jak i tylko świadomości, że na tę pomoc można liczyć. Ponadto za istotną cechę konstytuującą przyjaźń badanych, dorośli uznali także wzajemność. Należy jednak zauważyć, że mimo iż poprzez wzajemność przejawia się doznawanie i obdarzanie przyjaźnią, jej dobrowolność, cecha ta nie była dominującą dla respondentów. W podobny sposób respondenci ocenili ważność w przyjaźni otwartości, uznając, że jest to cecha istotna, ale niekonieczna. Badani, zarówno kobiety jak i mężczyźni nie uznali więc, że w przyjaźni najistotniejsze jest ujawnianie się, odsłanianie własnego „ja”. Za najmniej ważną respondenci uznali więź emocjonalną oraz intymność. Trzeba także podkreślić, że analizowane cechy społeczno-demograficzne nie wykazały cech istotności, jednak w przypadku płci da się zauważyć, iż więź emocjonalna okazała się cechą ważniejszą w przyjaźni dla kobiet niż mężczyzn, a wzajemność ważniejszą w przypadku mężczyzn niż kobiet.

\section{Cechy szczególnie cenione waktualnie trwających przyjaźniach}

Opinie respondentów na temat cech cenionych w aktualnie trwających przyjaźniach są zgodne z ogólną charakterystyką definicyjną tej relacji. Najistotniejszym czynnikiem związków przyjacielskich jest dla badanych, bez względu na wiek i płeć - zaufanie, będące jednym z podstawowych elementów przyjaźni. Przekonanie o możliwości polegania na przyjacielu, wiara w jego uczciwość to cecha, według respondentów, najwyżej hierarchizowana. Niemalże na tym samym poziomie została sklasyfikowana szczerość, która jest

2 Egzemplifikacją mogą być badania P. Wright’a, J. La Ggaipa. 
przejawem nie tylko właściwej komunikacji w interakcjach, ale także lojalności i uczciwości. Szczerość, podobnie jak otwartość czy możliwość zwierzania się jest w relacji przyjaźni ważniejsza dla kobiet niż dla mężczyzn. Ma to swoje uzasadnienie w badaniach, które wykazują, iż kobiety w większym zakresie niż mężczyźni odkrywają się i ujawniają (por. Skarżyska, 1979; Derlega, Chaikin, Stępień, 1979). Tak samo ważne dla respondentów są pomoc i wsparcie w przyjaźni, a więc jej aspekt utylitarny, oraz zrozumienie, akt wychodzący poza procesy poznawcze, przybierający formę empatycznej postawy i więzi emocjonalnej. Na uwagę zasługuje fakt, iż podobnie jak w przypadku analizy definicyjnej przyjaźni, najniższe rangi osiągnęły cechy wyznaczające bliskość relacji, a więc intymność i więź emocjonalna. Można przypuszczać, że w relacjach przyjacielskich badanych dorosłych istnieją takie sprawy, sytuacje, poglądy, które zaliczane są przez nich do kategorii tabu, czyli takich, które nie powierzane są nikomu (np. treści z zakresu ciała, seksu, zdrowia czy finansów). Wnioski te mogłyby potwierdzać inne polskie badania, $\mathrm{m}$. in. badania nad otwartością w stosunkach międzyludzkich L. Niebrzydowskiego i E. Płaszyńskiego (1989).

\section{Zakresy aktywności życiowych ${ }^{3}$ realizowanych wspólnie z przyjaciółmi}

Najczęściej wspólnie przez przyjaciół realizowaną aktywnością jest życie codzienne, nieco rzadziej życie rodzinne. Wykazano także, że zakresy aktywności uzależnione są od etapu dorosłości badanych, co może wskazywać na sytuację „wyznaczania” przyjaźni przez zadania rozwojowe $e^{4}$, jakie niesie ze sobą życie człowieka dorosłego. Obciążenie obowiązkami rodzinnymi, poszukiwanie „pokrewnej grupy społecznej”, poszukiwanie równowagi między pracą zawodową a życiem rodzinnym istotnie warunkuje codzienność, w której realizowana jest relacja przyjaźni.

3 Zakresy aktywności życiowej przyjęto za E. Dubas, Edukacja dorostych w sytuacji samotności i osamotnienia, Łódź, 2000.

4 Odwołanie do koncepcji zadań rozwojowych sformułowanych przez R. Havighursta (Przetacznik-Gierowska, Tyszkowa, 2000). 


\section{6 | Anna Gutowska}

\section{Edukacyjny wymiar przyjaźni}

Badania dotyczące uczenia się w sytuacji przyjaźni wykazały, że proces ten jest obecny w świadomości badanych dorosłych. Respondenci, bez względu na cechy społeczno-demograficzne, w zdecydowanej większości, dostrzegają możliwość uczenia się w przyjaźni. Uczenie się, w pewnym sensie, jest procesem naturalnym, gdyż każdy człowiek wykazuje wewnętrzną potrzebę przyswajania informacji, czyli naturalną ciekawość świata oraz potrzebę interakcji z otoczeniem. Najczęściej jednak uczenie kojarzone jest z jego formalną, instytucjonalną formą. W badanej grupie dorosłych rysuje się jednak orientacja na uczenie się w sytuacji przyjaźni, czyli uczenie się nieformalne. Znajduje to swoje potwierdzenie w założeniach M. S. Knowls'a, dla którego orientacja dorosłych na uczenie się koncentruje się na życiu (Knowls, Holton, Swanson, 2009, s. 46). Dorośli nabywają w ten sposób kompetencje, które pozwalają im radzić sobie z problemami, jakie napotykają w codzienności, a zdobyta wiedza i umiejętności mają bezpośrednie zastosowanie i mogą zostać wprowadzone w życie. W niniejszych badaniach potrzebę uczenia się w przyjaźni częściej odczuwały osoby starsze, natomiast młodzi ludzie, bez względu na płeć, w większości raczej nie. Istnieje prawdopodobieństwo, że uczenie się zostało przez młodych ludzi skojarzone z edukacją formalną, co być może niosło ze sobą negatywne konotacje. Potocznie uczenie się to obowiązek, często noszący pejoratywne znaczenie, a przyjaźń najczęściej spostrzegana jest jako wartość pozytywna. Ponadto analiza materiału badawczego wykazała, iż ponad połowa badanych dorosłych uważa, że zarówno w przeszłości jak i aktualnie uczy się w swoich przyjaźniach. Należy także dodać, że cechy społeczno-demograficzne nie mają istotnego wpływu na deklaracje uczenia się w sytuacji przyjaźni. Można jednak zauważyć pewne właściwości. Proces uczenia się w swoich aktualnie trwających przyjaźniach dostrzegało nieco więcej kobiet niż mężczyzn i nieco więcej respondentów młodych, a nie dostrzegała ponad połowa najstarszych kobiet.

W badanej populacji dorosłych proces wymiany między respondentami i ich przyjaciółmi częściej miał charakter dwukierunkowy, a więc wzajemny i najczęściej dotyczył sfery związanej z przeżywaniem różnych, codziennych i wyjątkowych sytuacji oraz z przekazywaniem sobie informacji. Jak twierdzą Sęk i Cieślak, wsparcie informacyjne może mieć charakter poznawczy, czyli wymiana informacji może służyć lepszemu zrozumieniu jakiejś sytuacji, położenia życiowego czy problemu, ale może także dostarczać informacji zwrotnych o skuteczności podejmowanych działań. Wsparcie informacyjne może też przybierać formę instruktażu, czyli polegać na przekazywaniu 
informacji o sposobach postępowania (Sęk, Cieślak, 2005, s. 19). Ponadto należy zauważyć, iż powyższa analiza potwierdza wcześniejsze spostrzeżenia, iż w badanej próbie dorosłych aspekt emocjonalny w przyjaźni jest stosunkowo mało istotny. Również w procesie wymiany pomiędzy przyjaciółmi ujawnianie prywatności - intymnych informacji, marzeń - osiągnęło niski poziom. Najrzadziej respondenci i ich przyjaciele wymieniali się usługami, czyli świadczoną na swoją rzecz działalnością o charakterze niematerialnym, której celem jest zaspokojenie określonych potrzeb (Jakubowicz, 1993). Badania sugerują, że oczekiwanie konkretnej pomocy ze strony partnera relacji nie odgrywa tak ważnej roli jak na przykład w przypadku stosunków rodzinnych. Arygle pisze, iż „przyjaźń została określona jako więź zbyt delikatna na to, by przetrwać naciski wynikające $\mathrm{z}$ dostarczania zasadniczej pomocy (...) (Arygle, 1991, s. 196).

\section{Wymiary uczenia się w sytuacji przyjaźni}

Analiza prowadzona $\mathrm{w}$ trzech wymiarach: poznawczym, emocjonalnym i społecznym ${ }^{5}$ wykazała, że badani dorośli uczą się w swoich przyjaźniach w każdym z nich, przy czym nieco częściej w społecznym. W wymiarze poznawczym najwięcej osób uczy się nowych umiejętności oraz poszerza wiedzę i umiejętności. W wymiarze emocjonalnym najwięcej badanych dorosłych uczy się postawy otwartości, zaś w wymiarze społecznym najczęściej ma miejsce uczenie się lepszego porozumiewania się z innymi ludźmi, udzielania wsparcia i rozwiązywania konfliktów. Na podstawie porównania częstotliwości wskazań w poszczególnych wymiarach można wnioskować, iż uczenie się w sytuacji przyjaźni najsilniej uwidocznione jest w wymiarze społecznym, następnie w wymiarze emocjonalnym, najsłabiej zaś w wymiarze poznawczym, jednak różnice te nie są znaczące.

Procesy poznawcze to procesy aktywnego przetwarzania informacji, wymagające wykorzystywania dotychczasowej wiedzy lub też prowadzące do uzyskania nowej. Obejmują one problematykę między innymi spostrzegania, pamięci, uwagi czy języka, ale także kodowania pozyskanych informacji oraz przetwarzania ich na struktury użytkowe i umiejętności (Maruszewski, 2001). K. Illeris w książce „Trzy wymiary uczenia się” cytuje amerykańskiego teoretyka uczenia się Dawida Ausubela, który twierdzi, że „najważniejszym czynnikiem wpływającym na uczenie się jest to, co uczeń

5 Wymiary uczenia się przyjęto za K. Illerisem, Trzy wymiary uczenia się, Wrocław, 2006. 
już wie" (za: Illeris, 2006, s. 38). Szczególne znaczenie ma to w przypadku uczniów dorosłych, którzy, jak piszą A. Matlakiewicz i H. Solarczyk-Szwec, nie są pustymi naczyniami, w których można umieścić wiedzę, „ale są osobami, które przepuszczają przez własne sito poznawcze odbierane informacje, lokują je w określonym kontekście" (2009, s. 42). Stwierdzenie to znajduje swoje uzasadnienie w materiale badawczym, gdzie respondenci stosunkowo rzadko deklarowali zdobywanie w sytuacji przyjaźni nowej wiedzy. Częściej poszerzali, wzbogacali, doskonali wiedzę i umiejętności już posiadane, nabyte w trakcie dotychczasowego życia.

$\mathrm{Z}$ analizy pozyskanego materiału empirycznego można wysunąć spostrzeżenie, że badani dorośli najczęściej w swoich przyjaźniach uczyli się postawy otwartości. Otwartość jest jednym z elementów konstytuujących przyjaźń. Odkrywanie przed przyjacielem własnego „ja” powoduje zwiększenie bliskości i przywiązania. Postawa taka sprzyja wzajemnej personalizacji upodmiotowieniu także $w$ innych typach relacji, ma więc swoje przełożenie na funkcjonowanie społeczne. Najrzadziej badani dorośli uczyli się w przyjaźni pogłębiania więzi duchowej, a więc tej najbardziej osobistej. Można przypuszczać, na co wskazują dotychczasowe wyniki badań, że w badanej populacji sfera ta jest zaliczana do najbardziej intymnych, do obszarów, które w pewnym sensie stanowią „tabu”, którym niechętnie się dzielą.

W niniejszych badaniach nieco silniej uwidoczniony został wymiar społeczny uczenia się w sytuacji przyjaźni, a elementy konstytuujące ten wymiar w dużej mierze zaliczyć można do kompetencji (umiejętności) społecznych osób dorosłych (za: Urbański-Korż, 2000). Skuteczniejsze porozumiewanie z ludźmi (nadawanie i odbieranie komunikatów werbalnych i pozawerbalnych), skuteczne rozwiązywanie konfliktów (konstruktywne zmiany), udzielanie wsparcia, to sprawności działaniowe, które istotnie wpływają na społeczne zachowania człowieka. Należy także zauważyć, że opanowanie tych umiejętności może mieć wpływ na pełnienie przez dorosłych różnych ról społecznych ${ }^{6}$. Każdy człowiek żeby móc sprawnie, czyli według T. Kotarbińskiego skutecznie, sprawnie i godziwie funkcjonować w środowisku społecznym, musi posiadać ku temu odpowiednie kompetencje. Dzieci, młodzież nabywają je w procesie socjalizacji, a dorośli doskonalą w sposób naturalny. Miejscem naturalnego treningu kompetencji społecznych badanych dorosłych jest także, jak wynika $z$ analizy materiału badawczego, sytuacja przyjaźni.

6 Zob. Goleman D., Inteligencja emocjonalna, Poznań, 1997. 
Stosunki interpersonalne, których przyjaźń jest bliską formą, są najczęściej uświadomionym przez respondentów obszarem uczenia się w przyjaźni. Badani dostrzegają zatem, że poprzez sam fakt wchodzenia w interakcje z przyjacielem może zachodzić proces uczenia się $\mathrm{w}$ stosunkach interpersonalnych. Dobre relacje gwarantują powodzenie i sukcesy życiowe. Przekonanie o możliwości budowania pozytywnych relacji, wpływie na ich funkcjonowanie sprawia, że dorośli są zainteresowani tym zagadnieniem i poszukują źródeł wiedzy na ten temat. Wśród nich J. Kargul wymienia poradniki, publikacje w czasopismach, audycje radiowe i telewizyjne (2005, s. 82). Istotnym źródłem informacji jest aktualnie również Internet, a także podróże, które stwarzają możliwość obserwacji zachowań ludzi o odmiennej kulturze. J. Kargul uważa, że „w stosunkach interpersonalnych człowiek dorosły ma możliwość obserwowania cudzych sposobów działania i myślenia, konfrontowania ich z własnymi, konfrontowania własnej sprawności manualnej czy intelektualnej ze sprawnością innych ludzi" (2005, s. 86-87). Obserwacja i refleksja mogą stymulować do zdobywania nowej wiedzy, czy skutkować utrwaleniem się nowych wzorów zachowań. Zdobyta w ten sposób wiedza może być elementem świadomości, który pozwoli na zrozumienie zachowania innych ludzi i siebie samego (Kargul, 2005, s. 89 i inne).

Analiza materiału badawczego ujawniła, że badani najczęściej deklarowali uczenie się w zakresie życia rodzinnego - jednego z głównych obszarów działalności człowieka dorosłego. Przyjaźń, zaliczana do bardzo bliskich relacji międzyludzkich, może stanowić źródło konfliktu ról społecznych (np. poprzez wybór między czasem przeznaczonym na obowiązki domowe, rodzicielski, małżeńskie itp., a czasem poświęconym przyjacielowi), może też być obszarem ściśle łączącym się z życiem rodzinnym. Respondenci uczestnicząc wzajemnie lub jednostronnie w życiu swoich rodzin internalizują tradycyjne wzory charakterystyczne dla mikrosystemu danej rodziny zazwyczaj w procesie naturalnej edukacji. Rodzina może być rozumiana nie tylko jako miejsce spotkań przyjaciół, ale także przestrzeń problemów, trudności, ale i sukcesów i radości, które dzieli się wspólnie z przyjacielem. Te sytuacje niosą ze sobą niejednokrotnie wymiar edukacyjny.

Porównanie analizy zakresów aktywności życiowych realizowanych przez respondentów wspólnie z przyjaciółmi z zakresami tejże aktywności, w których respondenci się uczą należy zauważyć, że są one ze sobą w dużym stopniu zbieżne, a w niektórych przypadkach wręcz się pokrywają. Ma to miejsce w odniesieniu do życia codziennego i rodzinnego. W tych wymiarach badani najczęściej realizowali wspólną aktywność życiową i w tych najczęściej się uczyli. Widoczna jest więc zależność, że im częściej dana aktyw- 
ność jest wspólnie w przyjaźni realizowana tym częstsza sytuacja uczenia się w niej.

\section{Bariery uczenia się w sytuacji przyjaźni}

Dla badanych dorosłych bariery utrudniające uczenie się w sytuacji przyjaźni są tożsame z czynnikami zaburzającymi przyjaźń. Badani uznali, iż najistotniejszą barierą jest różne rozumienie przyjaźni. Sposób pojmowania tej relacji zmienia się, wciąż bowiem dokonuje się "przebudowa” w dziedzinie ludzkich wartości, moralności, uczuć. Pojawiają się „odmiany” przyjaźni i różne jej style. Różni ludzie w różny sposób mogą przyjaźń realizować. Jak pisze M. Kozakiewicz, we współczesnych czasach następuje stopniowy zanik uczuć miłosnych, przyjacielskich. Zdaniem tego autora jest to wynikiem „masowego niepokoju i bezładu myśli wywołanych zawrotnym rytmem życia i pracy, w którym na wszystko brak czasu" (1995, s. 17). Związki międzyludzkie są coraz bardziej powierzchowne i płytkie. Nie oznacza to jednak, iż nie są one dla uczestników znaczącymi relacjami. Jednak różne rozumienie przyjaźni i wynikających z niej obowiązków może istotnie wpływać nie tylko na samą relację, ale także uczenie się w tej sytuacji.

Przyjaźń jest relacją, która nie polega tylko na doznawaniu, ale także na czynnym uczestnictwie. Wymaga zaangażowania, które przejawia się między innymi w działaniach mających na celu utrzymanie związku, działaniach ukierunkowanych na przyjaciela. Jest zwykle rezultatem świadomych decyzji. W subiektywnym przeżywaniu przyjaźni zaangażowanie odgrywa więc kluczową rolę. Istotną miejsce zajmuje także w procesie uczenia się. Brak zaangażowania jest zaliczany do zasadniczych czynników utrudniających, a nawet blokujących proces uczenia się dorosłych. Może on być wielorako uwarunkowany, między innymi. brakiem czasu, brakiem zainteresowania, złym nastawieniem do uczenia się czy brakiem motywacjī Brak zaangażowania w przyjaźni, który destrukcyjnie wpływa na wzajemność w związku, przekłada się więc także na uczenie się w tej relacji. Zaangażowanie, to możliwość kontaktowania się, działania, realizowania wspólnych spraw, to proces odchodzenia od kontaktów powierzchownych do sytuacji zażyłości, bliskości, intymności, sprzyjających wymianie i procesowi uczenia się.

7 Więcej na ten temat piszą A. Matlakiewicz H. Solarczyk-Szwec w książce Dorośli uczą się inaczej s. 40-42. 
We współczesnej psychologii można odnaleźć wiele przykładów badań potwierdzających, że podobieństwo ma duży wpływ na ocenę atrakcyjności drugiej osoby, przy czym nie jest ono ograniczone jedynie do wyglądu zewnętrznego, czy cech osobowościowych, ale także między innymi do zainteresowań, form spędzania czasu wolnego czy przekonań i poglądów. A.M. Pines powołując się na badania Byrne'a podaje, iż wykazał on, że osoby o podobnych do nas poglądach niejako potwierdzają słuszność naszych przekonań i przez to wydają się nam bardziej atrakcyjne $Z$ takimi osobami łatwiej nawiązujemy bliższe i głębsze relacje. Rozbieżność poglądów może zatem wpływać na wzajemną atrakcyjność przyjaciół, może także stać się przeszkodą w utrzymywaniu i rozwijaniu relacji, a co za tym idzie utrudnić czy wręcz uniemożliwić proces uczenia się w tej sytuacji. Wyniki niniejszych badań wskazują jednak, iż w opiniach badanych dorosłych czynnik ten nie należy do grupy istotnie utrudniających przyjaźnienie się i uczenie się w sytuacji przyjaźni (Pines, 2007).

Należy także zauważyć, iż podzielany przez przyjaciół system zainteresowań i poglądów okazał się w badanej grupie czynnikiem w małej mierze determinującym uczenie się w sytuacji przyjaźni. Według C. S. Lewisa „Przyjaźń rodzi się ze zwykłego koleżeństwa wówczas, gdy dwóch lub więcej kolegów stwierdzi, że posiadają podobną intuicję lub wspólne zainteresowania, albo nawet gusty, których inni nie mają i o których aż do tej chwili sądzili, że są wyłącznym ich skarbem (lub ciężarem)" (1993, s. 85-86). Wspólnota zainteresowań, to cecha często podkreślana przez badaczy przyjaźni. Już Arystoteles głosił, ze do zaistnienia, rozwoju i trwania przyjaźni konieczne jest podobieństwo zainteresowań i przekonań, a C. S. Lewis pisał, że przyjaźń „musi posiadać swój ośrodek, choćby nim była pasja do gry w domino lub do białych myszy" (tamże, s. 88). Sfera zainteresowań ma również istotne miejsce w przestrzeni edukacyjnej. Ich rozwój ma ważne znaczenie w wychowaniu, nauczaniu, kształtowaniu osobowości ${ }^{8}$. Uczenie się dorosłych, które opiera się na zainteresowaniach jest zgodne z potrzebami uczącego się, łączy się z miłymi doznaniami, a w konsekwencji warunkuje skutecz-

8 Zagadnieniu temu w swoich publikacjach dużo uwagi poświęciła A. Gurycka. Jest ona autorką modelowej definicji zainteresowań, która brzmi następująco: „Zainteresowanie jest to względnie trwała obserwowalna dążność do poznawania otaczającego świata przybierająca postać ukierunkowanej aktywności poznawczej o określonym nasileniu, przejawiająca się w selektywnym stosunku do otaczających zjawisk, to znaczy: 1 - w dostrzeganiu określonych cech przedmiotów oraz związków, zależności między nimi, a także wybranych problemów; 2 - w przeżywaniu różnorodnych uczuć (pozytywnych i negatywnych) związanych z nabywaniem i posiadaniem wiedzy" Rozwój i kształtowanie zainteresowań, Warszawa, 1989, s. 33-34. 
ne zapamiętywanie, bo jak piszą A. Matlakiewicz i H. Solarczyk-Szwec „Łatwiej zapamiętuje się treści zgodne z przekonaniami i postawami jednostki" (2009, s. 43). W ten sposób zdobyta wiedza nie ma "sakralnego” charakteru, ani nienaruszalnej struktury, ale jest zespołem wyselekcjonowanych według jej użytkownika prawd (Malewski, 2001, s. 277). Argumenty te nie znalazły jednak uzasadnienia w prezentowanych badaniach. Rozbieżność zainteresowań, która może stanowić istotną barierą uczenia się w sytuacji przyjaźni, w opiniach badanych dorosłych nie znalazła swojego potwierdzenia. Nie można wykluczyć, iż nie wszyscy respondenci mieli skonkretyzowane zainteresowania, oraz że angażowali się w tę sferę wspólnie z przyjaciółmi.

Niski poziom istotności zakłócania procesu uczenia się w sytuacji przyjaźni osiągnęły kategorie związane ze sferą emocjonalno-uczuciową. Jak pisze K. Illeris do funkcjonowania struktur poznawczych niezbędne są czynniki afektywne (2006, s. 71 i dalsze). Afektywność jest kluczowym elementem motywującym, nadającym subiektywność znaczeniom i wyznaczającym indywidualny potencjał działania. „Sfera emocjonalna i poznawcza wykształcają się w pewnej całości i zawsze funkcjonują ze sobą w ścisłym związku" (tamże, s. 80). Czynniki afektywne, które kształtują emocje osób uczących się, w procesie poznawczym mają istotny wpływ na przebieg i skuteczność uczenia się, tj. mogą go zarówno zakłócać, jak i skutecznie wspomagać. Badania naukowe pokazują, że efektywne uczenie się zachodzi w tzw. pozytywnym cyklu poznawczym ${ }^{9}$, czyli przy dominacji pozytywnych emocji. Zakładając, że przyjaźni towarzyszą zazwyczaj takie emocje jak: zadowolenie, radość, poczucie szczęścia ${ }^{10}$ można przyjąć, iż relacja ta niesie ze sobą sytuacje korzystne $z$ tego punktu widzenia. Założenia te nie znajdują jednak potwierdzenia w niniejszych badaniach.

\section{Podsumowanie}

Przyjaźń badanych dorosłych jawi się jako uniwersalne zjawisko ludzkiego życia. Uniwersalność przyjaźni przejawia się w jej ponadczasowości, określaniu życia człowieka dorosłego na wszystkich etapach dorosłości w kategoriach ogólnoludzkich. Uniwersalny charakter przyjaźni wynika także

9 Takiego pojęcia używa Z. Megier w artykułach Czynniki afektywne w zdalnej edukacji i Strategie motywacyjno-wolitywne w edukacji zdalnej opublikowanych w 3 i 5 numerze z 2008 r. czasopisma „e-mentor”.

10 W niniejszych badaniach przyjęto, że przyjaźń jest relacją pozytywną i nie zajmowaną się jej aspektem negatywnym. 
z faktu, iż istotnego wpływu na jej obraz i funkcjonowanie nie mają cechy społeczno-demograficzne.

Przyjaźń badanych dorosłych jest „składnikiem” ich codzienności. Relacja ta najsilniej wpisana jest w życie codzienne dorosłych, które związane jest także z życiem rodzinnym i pracą zawodową. Rodzina i praca to dwa obszary, wokół których koncentruje się życie człowieka dorosłego i które istotnie określają jego codzienność.

Badania potwierdziły obecny $\mathrm{w}$ andragogice paradygmat związany $\mathrm{z}$ edukacyjnym wymiarem dorosłości. Uczenie się (zakładając szeroką definicję tego pojęcia) obecne jest w życiu człowieka na przestrzeni całej jego biografii. Uczenie się w sytuacji przyjaźni, wykraczające poza mury instytucji, realizowane na tle życia, nie tylko obecne jest w życiu dorosłych, ale także, w świetle tych badań, zazwyczaj uświadomione i dostrzegane.

Przyjaźń jest sytuacją uczenia się, a zakres treści uczenia się w tej relacji wynika przede wszystkim z zakresu aktywności życiowych realizowanych wspólnie przez uczestników relacji. Uczenie się w sytuacji przyjaźni najsilniej wpisane jest w życie codzienne dorosłych. Jest procesem związanym z życiem codziennym i można wręcz powiedzieć, że „znosi granice pomiędzy uczeniem się i życiem" (West, 2003, s. 7). Uczenie się w sytuacji przyjaźni w życiu codziennym ma charakter permanentny, ciągły, dzieje się niejako „przy okazji” przyjaźnienia.

Uczenie się w sytuacji przyjaźni badanych ujawnia się przede wszystkim w wymiarze emocjonalnym i społecznym. Znajduje to swoje uzasadnienie w charakterze relacji. Emocjonalny wymiar uczenia się w przyjaźni przejawia się przede wszystkim w zdobywaniu i doskonaleniu umiejętności trafnego odczytywania emocji oraz komunikowania i wyrażania własnych uczuć i emocji. W wymiarze społecznym uczenie się w sytuacji przyjaźni przejawia się przede wszystkim poprzez mechanizm internalizacji postaw, zachowań w różnych sferach życia społecznego. Oba wymiary zawierają składowe indywidualne, jak i społeczne, przejawiają się zarówno w bezpośrednim i pośrednim sensie, tzn. wpływają na charakter interakcji w przyjaźni, a także na poziomie innych interakcji społecznych.

Uczenie się w sytuacji przyjaźni przebiega w obszarach życia najbardziej wyeksponowanych ze względu na etap dorosłości. Najczęściej przejawia się w obszarze stosunków interpersonalnych i życia rodzinnego. Najrzadziej w obszarze cielesności. Obszar ten, nie został przez badanych dorosłych włączony w przestrzeń edukacyjną przyjaźni. Uczenie się w sytuacji przyjaźni w obszarze stosunków międzyludzkich odnosi się zarówno do 


\section{4 | Anna Gutowska}

bezpośrednich relacji w przyjaźni, jak i pośrednich skutków przejawiających się $\mathrm{w}$ interakcjach $\mathrm{z}$ innymi ludźmi.

Przyjaźń jawi się jako obszar, w którym człowiek dorosły w sposób niezaplanowany i niezorganizowany uczy się w sytuacjach codziennych. Wyniki potwierdzają, iż edukacja osób dorosłych przestaje być ujmowana jedynie jako kategoria kształcenia formalnego, zinstytucjonalizowanego i „wychodzi” poza systemy edukacyjne, a człowiek dorosły, jako „podmiot poznający", dostrzega proces uczenia się nieformalnego. Emancypacja wiedzy i uczenia się z ram edukacji instytucjonalnej umożliwiła badaczom sięgnięcie po takie obszary uczenia się, które dotąd były niedostępne, zarówno z powodów teoretycznych, jak i metodologicznych. Andragodzy zyskali autonomię poznawczą pozwalającą na eksplorację całożyciowego uczenia się. Dlatego konieczne są próby dalszej penetracji empirycznej, które pozwoliłaby, być może lepiej zrozumieć czego, jak uczą się i rozwijają ludzie dorośli w warunkach współczesnego świata.

\section{Bibliografia}

Alberoni F. (1994) O przyjaźni, Instytut Kultury, Warszawa.

Aronson E. (1995) Człowiek - istota społeczna, PWN, Warszawa.

Argyle M. (1991) Psychologia stosunków międzyludzkich, PWN, Warszawa.

Derlega V. J., Chaikin A. L., Stępień E. (1979) Intymność i otwartość w stosunkach interpersonalnych, „Przegląd Psychologiczny” nr 2.

Dominicé P. (2006) Uczyć się z życia. Biografia edukacyjna w edukacji dorostych, Wydawnictwo WSH-E, Łódź.

Dubas E. (2000) Edukacja dorostych w sytuacji samotności i osamotnienia, Wyd. UŁ, Łódź.

Dubas E. (2009) Etapy dorosłości i proces kształcenia w: A. Fabiś, B. Cyboran (red.), Dorosty w procesie kształcenia, Bielsko-Biała- Zakopane, s. 115-132.

Erikson E. (2002) Dopetniony cykl życia, REBIS, Poznań.

Illeris K. (2006) Trzy wymiary uczenia się, Wydawnictwo Naukowe DSWE TWP, Wrocław.

Kargul J. (2005) Obszary pozaformalnej i nieformalnej edukacji dorostych. Przestanki do budowy teorii edukacji całożyciowej, Wyd. Naukowe DSWE TWP, Wrocław.

Knowles M. S., Holton E. F. III, Swanson R. (2009) Edukacja dorostych. Podręcznik akademicki, PWN, Warszawa.

Lewis C. S. (1993) Cztery miłości, Instytut Wydawniczy PAX, Warszawa.

Malewski M. (2001) Modele pracy edukacyjnej z ludźmi dorosłymi, (w:) E. Przybylska (red.) Andragogiczne wątki, poszukiwania, fascynacje, Torun. 
Malewski M. (2010) Od nauczania do uczenia się. O paradygmatycznej zmianie $w$ andragogice, Wydawnictwo Naukowe DSWE, Wrocław.

Matlakiewicz A., Solarczyk-Szwec H., (2009) Dorośli uczq̨ się inaczej. Andragogiczne podstawy kształcenia ustawicznego, Wyd. CKU w Toruniu, Toruń.

Maruszewski T. (2001) Psychologia poznania, GWP, Gdańsk.

Niebrzydowski L., Płaszczyński E. (1989) Przyjaźń i otwartość w stosunkach międzyludzkich, Warszawa.

Pahl R. (2008) Przyjaźń - społeczne spoiwo wspótczesnego społeczeństwa?, (w:) P. Sztompka, M. Bogunia-Borowska (red.), Socjologia codzienności, Wydawnictwo Znak, Kraków, s. 160-180.

Przetacznik-Gierowska M., Tyszkowa M. (2000) Psychologia rozwoju człowieka, PWN, Warszawa.

Radziewicz-Winnicki A. (red.) (2002) Edukacja a życie codzienne, t.1, Wyd. UŚ, Katowice.

Sęk H., Cieślak R. (red.) (2005) Wsparcie społeczne, stres i zdrowie, PWN, Warszawa. Schopenhauer A. (1903) Psychologia miłości, Księgarnia M. Borkowskiego, Warszawa. Stewart J. (red.) (2000) Mosty zamiast murów. O komunikowaniu się między ludźmi, PWN, Warszawa.

West 1., (2003) Wstęp. Obszary sporu: badania nad edukacją i całożyciowym uczeniem się w Wielkiej Brytanii, „Teraźniejszość, Człowiek, Edukacja”, nr 1.

Wojciszke B. (2004), Psychologia miłości. Intymność. Namiętność. Zaangażowanie, GWP, Gdańsk. 